\title{
Social Mobility and Political Change
}




\section{Key Concepts in Political Science GENERAL EDITOR: Leonard B. Schapiro eXeCUTIVe EDITOR: Peter Calvert}

Other titles in the same series include:

ALREADY PUBLISHED

Martin Albrow

Bureaucracy

IN PREPARATION

Shlomo Avinieri

Stanley Benn

Anthony H. Birch

Peter Calvert

Brian Chapman

Karl Deutsch

S. E. Finer

Joseph Frankel

C. J. Friedrich

Julius Gould

Eugene Kamenka and
Utopianism

Power

Representation

Revolution

Police State

Legitimacy

Dictatorship

National Interest

Tradition and Authority

Violence

Alice Erh-Soon Tay Law

J. F. Lively

Robert Orr

Democracy

P. H. Partridge

John Plamenatz

John C. Rees

Bernard Schaffer

Leonard B. Schapiro

Henry Tudor

Liberty

Consent and Consensus

Ideology

Equality

Modernization

Totalitarianism

Political Myth 


\section{Social Mobility}

and Political

Change

\section{Ioan Davies}

\section{University of Essex}


(C) 1970 by Pall Mall Press Ltd. London First published in 1970 by Pall Mall Press Itd

This edition published in 1970 by Macmillan and Company Limited Little Essex Street London wc2 and also at Bombay Calcutta and Madras Macmillan South Africa (Publishers) Pty Ltd Johannesburg The Macmillan Company of Australia Pty Ltd Melbourne The Macmillan Company of Canada Ltd Toronto Gill and Macmillan Ltd Dublin SBN (Paper) 333112644

ISBN 978-1-349-00922-0

ISBN 978-1-349-00920-6 (eBook) DOI 10.1007/978-1-349-00920-6

Papermacs are sold subject to the condition that they shall not, by way of trade or otherwise, be lent, re-sold, hired out, or otherwise circulated without the publisher's prior consent in any form of binding or cover other than that in which they are published and without a similar condition including this condition being imposed on the subsequent purchaser. 


\section{Contents}

'Key Concepts'

an Introductory Note

Preface and Acknowledgements

1/Political Theory and Social Mobility

The classical theories

Mobility and political organizations

2/Political Systems and Social Stratification

The development of political structures

Classification and comparison

3/Mobility and Social and Political Consequences

4/Mobilization, Mobility and Political Development

Industrial workers and mobilization

\section{5/Mobility and Politics in Industrial Society}

Differentiation and political change

The affluent worker and the 'new' working class

Negroes, downward mobility and political radicalism 


\section{6/Differentiation and Political Power 96}

Classification of social structures $\quad 96$

The élite and new sectors 103

Mobility and political change $\quad 108$

Notes and References $\quad 115$

Bibliography $\quad 121$

$\begin{array}{ll}\text { Index } & 128\end{array}$ 


\section{'Key Concepts' an Introductory Note}

Political concepts are part of our daily speech-we abuse 'bureaucracy' and praise 'democracy', welcome or recoil from 'revolution'. Emotive words such as 'equality', 'dictatorship', 'élite' or even 'power' can often, by the very passions which they raise, obscure a proper understanding of the sense in which they are; or should be, or should not be, or have been used. Confucius regarded the 'rectification of names' as the first task of government. 'If names are not correct, language will not be in accordance with the truth of things', and this in time would lead to the end of justice, to anarchy and to war. One could with some truth point out that the attempts hitherto by governments to enforce their own quaint meanings on words have not been conspicuous for their success in the advancement of justice. 'Rectification of names' there must certainly be: but most of us would prefer such rectification to take place in the free debate of the university, in the competitive arena of the pages of the book or journal.

Analysis of commonly used political terms, their reassessment or their 'rectification', is, of course, normal activity in the political science departments of our universities. The idea of this series was indeed born in the course of discussion between a few university teachers of political science, of whom Professor S. E. Finer of Manchester University was one. It occurred to us that a series of short books, discussing the 'Key Concepts' in political science would serve two purposes. In universities these books could provide the kind of brief political texts which might be of assistance to students in gaining a fuller understanding of the terms which they were constantly using. But we also hoped that outside the universities there exists a reading public which has the time, the curiosity and the inclination to pause to reflect on some of those words and ideas which are so often taken for granted. Perhaps even 'that insidious and crafty animal', as Adam Smith described the politician and statesman, will occasionally derive some pleasure or even profit from that more leisurely analysis which academic study can afford, and which a busy life in the practice of politics often denies. 


\section{8/'Key Concepts' an Introductory Note}

It has been very far from the minds of those who have been concerned in planning and bringing into being the 'Key Concepts' series to try and impose (as if that were possible!) any uniform pattern on the authors who have contributed, or will contribute, to it. I, for one, hope that each author will, in his own individual manner, seek and find the best way of helping us to a fuller understanding of the concept which he has chosen to analyse. But whatever form the individual exposition may take, there are, I believe, three aspects of illumination which we can confidently expect from each volume in this series. First, we can look for some examination of the history of the concept, and of its evolution against a changing social and political background. I believe, as many do who are concerned with the study of political science, that it is primarily in history that the explanation must be sought for many of the perplexing problems of political analysis and judgement which beset us today. Second, there is the semantic aspect. To look in depth at a 'key concept' necessarily entails a study of the name which attached itself to it; of the different ways in which, and the different purposes for which, the name was used; of the way in which in the course of history the same name was applied to several concepts, or several names were applied to one and the same concept; and, indeed, of the changes which the same concept, or what appears to be the same concept, has undergone in the course of time. This analysis will usually require a searching examination of the relevant literature in order to assess the present stage of scholarship in each particular field. And thirdly, I hope that the reader of each volume in this series will be able to decide for himself what the proper and valid use should be of a familiar term in politics, and will gain, as it were, from each volume a sharper and bettertempered tool of political analysis.

There are many today who would disagree with Bismarck's view that politics can never be an exact science. I express no opinion on this much debated question. But all of us who are students of politics-and our numbers both inside and outside the universities continue to grow-will be the better for knowing what precisely we mean when we use a common political term.

London School of Economics and Political Science
Leonard B. Schapiro General Editor 


\section{Preface and \\ Acknowledgements}

The case for the consideration of social mobility as a concept used by political scientists rests on the obvious fact, noted by most commentators during the nineteenth century, that many of the political upheavals which characterized Western Europe and North America from the end of the eighteenth century were associated with changing patterns of social mobility. Since then, however, sociologists have paid much attention to social mobility, but not to its relationship with political change, while political scientists concerned with change have paid some attention to social stratification but not, on the whole, to mobility. This book is therefore to a large extent an attempt to return to some of the basic preoccupations of earlier political scientists while at the same time examining the accumulated knowledge and research which has unfortunately been affected by the division of the topic between two disciplines. There is considerable writing on the relationship between class, status and other stratification features and politics, but on the whole this has lacked the historical and dynamic emphasis which interested John Stuart Mill, de Tocqueville, Weber and Durkheim. Ultimately the importance of social stratification for the political scientist is not that societies have different measurements and dimensions of social inequality but that these forms of stratification are constantly changing. The important issue is whether changes in political structure necessarily affect social differences and vice versa.

By its very nature, such a study must be comparative, in time and across societies. As far as possible this book tries to base its account on as much comparative material as possible. Inevitably there are gaps. Asia is hardly treated at all, most of the historical evidence is ignored and the use of data in relation to particular theories is often random and purely illustrative. But to have been systematic and detailed as well as comparative would have required a much longer book. I can only hope that my suggestions of the importance and dimensions of the topic will stimulate the reader to examine this other material in greater detail. 
I am pleased to make certain acknowledgements. The major part of Chapter 4 appeared in the Socialist Register 1967 . (I must thank the editors, Ralph Miliband and John Saville, as well as the publishers, Merlin Press, for permission to reproduce material.) Shakuntala de Miranda helped with some of the basic research; she was a model of what an academic colleague should be. Many undergraduate and post-graduate students at the University of Essex read sections of the manuscript and commented. If there are any virtues in the book they come from the fact that it was written as part of a teaching programme. If there are any failings they show that the teacher was not as good as his students.

Colchester,

Ioan Davies

November, I969 